\title{
Sustainable technologies for recycling and reuse: an overview
}

\author{
Süreyya Meric ${ }^{1} \cdot$ Hüseyin Selcuk ${ }^{2} \cdot$ Burcu Onat $^{2} \cdot$ Atakan Ongen $^{2}$ \\ Received: 12 March 2016 / Accepted: 15 November 2017 / Published online: 19 January 2018 \\ (C) Springer-Verlag GmbH Germany, part of Springer Nature 2017
}

Recycling and reuse of water, air and soil pollutants, and wastes has been an emerging issue during the recent decade to protect natural resources and the environment (Corder et al. 2015; Colling et al. 2016). A number of national and international environmental programs and projects have been increasingly performed. The most recent outcomes of those projects/research have been published referring to mostly favor sustainable technologies for recycling and reuse of various resources that include energy recovery from organic fraction of municipal solid wastes (Cesaro et al. 2016), from food wastes (Karmee 2016), from wastewater treatment plant sludge (Batstone et al. 2015; ColmenarSantos et al. 2016), compost recovery from organic fraction of municipal solid waste (Cesaro et al. 2015), and fertilizers from wastewater (Hukari et al. 2016; Puchongkawarin et al. 2015; Shepherd et al. 2016). Various industrial wastes have been recycled to produce new products or reuse in the process purposes such as vehicle recycling processes ( $\mathrm{Li}$ et al. 2016), recycling schemes for waste dry batteries (Lin and Chiu 2015), of waste aggregate in cement bound mixtures for road pavement bases and sub-base (Pasetto and Baldo 2016), of waste automotive laminated glass and valorization of polyvinyl butyral (Swain et al. 2015), of blast furnace sludge (Drobíková et al. 2016), and recycling of electronic wastes (Awasthi et al. 2016). Besides advanced treatment technologies among which membranes are the common ones, have been applied for recycling and reuse of urban (Bunani et al. 2013) and industrial wastewaters (Zheng et al. 2015). Additionally, valorization of renewable energy

Responsible editor: Philippe Garrigues

Süreyya Meric

smeric@nku.edu.tr

1 Çorlu Engineering Faculty, Environmental Engineering Department, Namik Kemal University, 59860 Corlu, Tekirdağ, Turkey

2 Environmental Engineering Department, Istanbul University, Avcilar, 34320 Istanbul, Turkey sources has been a pioneering recycling and reuse sector (Byrnes et al. 2016; Sahoo 2016) that is somewhat discussed for not being green (Keramitsoglou et al. 2016) and causing environmental impact (Sokka et al. 2016).

This special issue is composed of a number of scientific works presented at the $2^{\text {nd }}$ International Conference on Recycling and Reuse, held on 4-6 June 2014 in Istanbul, Turkey. The biennial Conference was jointly organized by Bogazici University, Environmental Sciences Institute and Istanbul University, Environmental Engineering Department, Turkey. The purpose of the Conference was to provide an advanced platform for researchers and practitioners to exchange emerging ideas and to investigate key issues on whole and progressive aspects of recycling and reuse.

The Conference program included a wide spectrum of important topics in recycling and reuse concerns of wastewaters and wastes, advanced wastewater treatment, and membrane technologies for recycling and reuse. A total number of 90 oral and 155 poster presentations were given in the topics of advanced oxidation technologies, waste reduction, water and wastewater management, solid waste treatment and management, hazardous waste management, resource use, renewable energy technologies, current and future recycling markets, public health issues, and legislations and policies of recycling and reuse.

This special issue, specifically named "Sustainable Technologies for Recycling and Reuse" includes 4 papers that were selected among 25 invited papers submitted to an essential peer-review process. Three of the accepted papers present examples for removal of emerging pollutants using different advanced treatment options before reuse, and the other gives a case study on mercury containing substances flow in Turkey that would be a good example for policy decision support in developing countries as well.

The guest editors expect that this issue should provide an overview of recent works done in "Recycling and Reuse" fields and fulfills scientific gaps to provide an important contribution to scientific and technological communities. 
Acknowledgements The guest editors would like to express their gratitude to all participants for their valuable contributions, and special thanks go to Prof. Dr. Philip Garrigues for giving the opportunity to publish this special issue in ESPR Journal and Prof. Dr. Miray Bekbolet as the Cochair of the Conference.

\section{References}

Awasthi AK, Zeng X, Li J (2016) Environmental pollution of electronic waste recycling in India: a critical review. Environ Pollut 211:259 270. https://doi.org/10.1016/j.envpol.2015.11.027

Batstone DJ, Hülsen T, Mehta CM, Keller J (2015) Platforms for energy and nutrient recovery from domestic wastewater: a review. Chemosphere 140:2-11. https://doi.org/10.1016/j.chemosphere. 2014.10.021

Bunani S, Yörükoğlu E, Sert G, Yüksel Ü, Yüksel M, Kabay N (2013) Application of nanofiltration for reuse of municipal wastewater and quality analysis of product water. Desalination 315:33-36. https:// doi.org/10.1016/j.desal.2012.11.015

Byrnes L, Brown C, Wagner L, Foster J (2016) Reviewing the viability of renewable energy in community electrification: the case of remote Western Australian communities. Renew Sust Energ Rev 59:470 481. https://doi.org/10.1016/j.rser.2015.12.273

Cesaro A, Belgiorno V, Guida M (2015) Compost from organic solid waste: quality assessment and European regulations for its sustainable use. Resour Conserv Recycl 94:72-79

Cesaro A, Russo L, Farina A, Belgiorno V (2016) Organic fraction of municipal solid waste from mechanical selection: biological stabilization and recovery options. Environ Sci Pollut Res 23(2):15651575. https://doi.org/10.1007/s11356-015-5345-2.

Colling AV, Oliveira LB, Reis MM, da Cruz NT, Hunt JD (2016) Brazilian recycling potential: energy consumption and Green House Gases reduction. Renew Sust Energ Rev 59:544-549. https://doi.org/10.1016/j.rser.2015.12.233

Colmenar-Santos A, Zarzuelo-Puch G, Borge-Diez D, García-Diéguez C (2016) Thermodynamic and exergoeconomic analysis of energy recovery system of biogas from a wastewater treatment plant and use in a Stirling engine. Renew Energy 88:171-184. https://doi.org/10. 1016/j.renene.2015.11.001

Corder GD, Golev A, Giurco D (2015) "Wealth from metal waste": translating global knowledge on industrial ecology to metals recycling in Australia. Miner Eng 76:2-9. https://doi.org/10.1016/j.mineng. 2014.11.004

Drobíková K, Plachá D, Motyka O, Gabor R, Kutláková KM, Vallová S, Seidlerová J (2016) Recycling of blast furnace sludge by briquetting with starch binder: waste gas from thermal treatment utilizable as a fuel. Waste Manag 48:471-477. https://doi.org/10.1016/j.wasman. 2015.11.047

Hukari S, Hermann L, Nättorp A (2016) From wastewater to fertiliserstechnical overview and critical review of European legislation governing phosphorus recycling. Sci Tot Environ 542(( Part B)): $1127-1135$

Karmee SK (2016) Liquid biofuels from food waste: current trends, prospect and limitation. Renew Sust Energ Rev 53:945-953. https://doi. org/10.1016/j.rser.2015.09.041

Keramitsoglou KM, Mellon RC, Tsagkaraki MI, Tsagarakis KP (2016) Clean, not green: the effective representation of renewable energy. Renew Sust Energ Rev 59:1332-1337. https://doi.org/10.1016/j. rser.2016.01.005
Li W, Bai H, Yin J, Hu H (2016) Life cycle assessment of end-of-life vehicle recycling processes in China - take Corolla taxis for example. J Clean Prod 117:176-187. https://doi.org/10.1016/j.jclepro. 2016.01.025

Lin SS, Chiu KH (2015) An evaluation of recycling schemes for waste dry batteries - a simulation approach. J Clean Prod 93:330-338. https://doi.org/10.1016/j.jclepro.2015.01.045

Pasetto M, Baldo N (2016) Recycling of waste aggregate in cement bound mixtures for road pavement bases and sub-bases. Constr Build Mater 108:112-118. https://doi.org/10.1016/j.conbuildmat. 2016.01.023

Puchongkawarin C, Gomez-Mont C, Stuckey DC, Chachuat B (2015) Optimization-based methodology for the development of wastewater facilities for energy and nutrient recovery. Chemosphere 140: 150-158. https://doi.org/10.1016/j.chemosphere.2014.08.061

Sahoo SK (2016) Renewable and sustainable energy reviews solar photovoltaic energy progress in India: a review. Renew Sust Energ Rev 59:927-939. https://doi.org/10.1016/j.rser.2016.01.049

Shepherd JG, Sohi SP, Heal KV (2016) Optimising the recovery and reuse of phosphorus from wastewater effluent for sustainable fertiliser development. Water Res 94:155-165. https://doi.org/10.1016/j. watres.2016.02.038

Sokka L, Sinkko T, Holma A, Manninen K, Pasanen K, Rantala M, Leskinen P (2016) Environmental impacts of the national renewable energy targets - a case study from Finland. Renew Sust Energ Rev 59:1599-1610. https://doi.org/10.1016/j.rser.2015.12.005

Swain B, Park JR, Shin DY, Park KS, Hong MH, Lee CG (2015) Recycling of waste automotive laminated glass and valorization of polyvinyl butyral through mechanochemical separation. Environ Res 142:615-623. https://doi.org/10.1016/j.envres.2015.08.017

Zheng X, Zhang Z, Yu D, Chen X, Cheng R, Min S, Wang J, Xiao Q, Wang $J(2015)$ Overview of membrane technology applications for industrial wastewater treatment in China to increase water supply. Resour Conserv Recycl 105(Part A):1-10

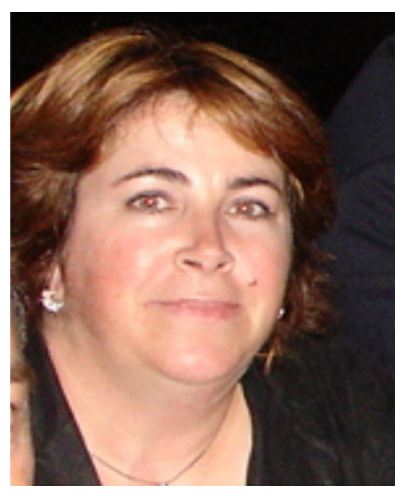

Süreyya Meriç, Full Professor, holds BSc degrees in Environmental Engineering from Istanbul Technical University (ITU), Turkey and MSc (1990), and $\mathrm{PhD}$ (1997) from ITU Institute of Sciences. She worked as Research Assistant and Assistant Professor at ITU from 1988 to 2004. She was awarded fellowship from Italian Ministry of Foreign Affairs from 1999 to 2000 at the University of Naples Federico II. She collaborated with the University of Salerno (Italy) from 2004 to 2010. She has developed a long-lasting expertise in advanced (waste)water treatment technologies, recycling and reuse, alternative water sources development, and ecotoxicology. She has coordinated or took part in many national and international projects and supervised a number of graduate theses. She has been an invited speaker at international institutions and symposiums. She was enrolled in organizing scientific committees at national and international symposiums, conferences, and summer schools. She acted as guest editor for special issues of SCI Journal, edited book chapters, published more than 90 SCI papers having over 4700 citations (h index of 32). 


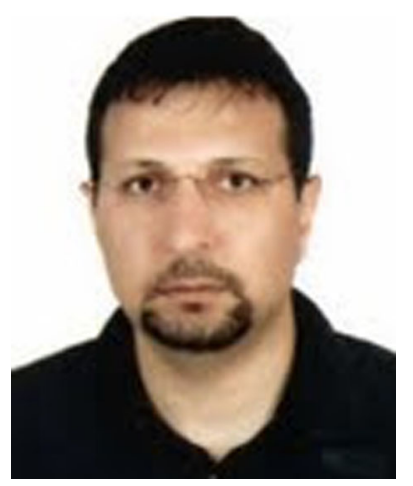

Huseyin Selcuk, Full Professor, is enrolled as Head of the Department at Istanbul University. In 2001, he was visiting researchers in the Water Chemistry Department at the University of WisconsinMadison. He received his $\mathrm{PhD}$ degree in 2004 from Environmental Engineering Program of ITU, Applied Sciences Institute, Turkey. He has developed expertise in disinfection-disinfection by-products, advanced treatment of water and wastewater and reuse. He has coordinated many national and international projects. He participated in the editing of a book of "Advances in Control of Disinfection By-Products in Drinking Water Systems" (NOVA). He has published more than 35 SCI papers and has given many invited presentations at the international venues and summer school. He acted as cochair of the International Workshop on Urbanization, Land Use, Land Degradation and Environment (http://ule2009.pau.edu.tr) and initiated International Recycling and Reuse Conference as co-chair with Prof. Dr. Miray Bekbölet in 2012 (http://istanbul.rr2014.edu.tr).

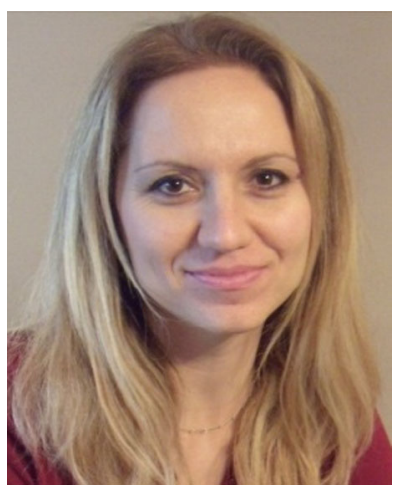

Burcu Onat, Associate Professor, received her $\mathrm{PhD}$ in 2004 in Faculty of Engineering, Department of Environmental Engineering from Istanbul University (IU). She served as research assistant at IU from 1995 to 2000. She worked as Health, Safety and Environmental Engineer at Power Plant Project in Baku, Azerbaijan, from 2000 to 2003. She has been working at Environmental Engineering Department at IU since 2006. Her scientific area of interest involves air pollution, air quality modeling, emission control, indoor air quality, and traffic-sourced emissions. She has been awarded research grants by The Turkish Scientific and Technological Research Council at the University of Birmingham, School of Geography, Earth and Environmental Science, England, between June 2013 and December 2013. She has been involved in several national and international projects related to urban air quality, traffic emissions, and heavy metal pollution in air. She has published $21 \mathrm{SCI}$ indexed papers and submitted more than 50 oral/poster presentations in national and international scientific organizations.

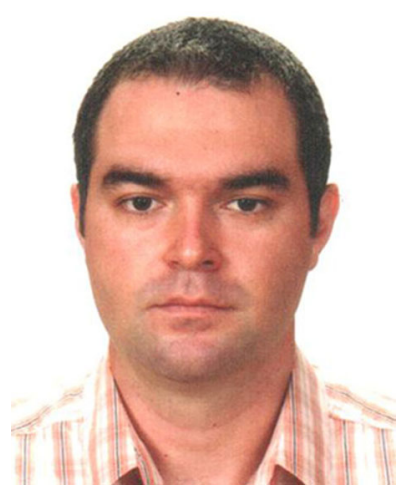

Atakan Ongen, Assistant Professor, received his $\mathrm{PhD}$ in 2011 in Faculty of Engineering, Department of Environmental Engineering from Istanbul University (IU). He served as research assistant at Trakya University and Namik Kemal University, Çorlu, Tekirdağ from 2001 to 2010. He has been working at Environmental Engineering Department at IU for 4 years. His scientific area of interest involves environmental pollution control, waste-to-energy concept, thermochemical processes, and waste management. He has been awarded research grants by The Turkish Scientific and Technological Research Council at the University of Ontario, Canada (April 2015-September 2015). He has been involved in several national projects. He has published $15 \mathrm{SCI}$ indexed papers, submitted more than 40 oral/poster presentations in national and international scientific organizations, 4 chapters in international books, and served as a referee for more than 20 SCI journals. 